\title{
POZNAVANJE DOMAĆIH ŽIVOTINJA KOD UČENIKA NIŽIH RAZREDA OSNOVNIH ŠKOLA GRADA ZAGREBA
}

\author{
HOW MUCH DO STUDENTS IN JUNIOR GRADES OF PRIMARY \\ SCHOOLS IN ZAGREB KNOW ABOUT DOMESTIC ANIMALS
}

\author{
Ivana Sever, Marina Vranić, K. Bošnjak, Ivana Čačić, \\ Martina Protulipac, Mirjana Klepac
}

\section{SAŽETAK}

U brojnim je istraživanjima utvrđen pozitivan utjecaj životinja na kvalitetu života ljudi. Utvrđeno je da životinje pozitivno utječu na psihičko i fizičko zdravlje ljudi, potiču ljude na društvene i fizičke aktivnosti, a često se koriste u terapeutske svrhe. Ciljevi ovog istraživanja bili su utvrditi: (I) koliko učenici nižih razreda osnovnih škola poznaju domaće životinje, (II) postoje li razlike u poznavanju domaćih životinja kod djevojčica u odnosu na dječake, (III) postoje li razlike u poznavanju domaćih životinja između učenika drugog, trećeg i četvrtog razreda, (IV) mišljenje učiteljica o poznavanju domaćih životinja učenika nižih razreda. Istraživanje je provedeno na pokušalištu Sveučilišta u Zagrebu Agronomskog fakulteta Centar za travnjaštvo, anketiranjem učenika i njihovih učiteljica tijekom školske godine 2016./2017. Obuhvaćeno je ukupno 528 učenika nižih razreda (od 2. do 4. razreda) iz 7 osnovnih škola Grada Zagreba od čega 259 dječaka i 269 djevojčica, te 28 učiteljica. Rezultati su pokazali da izgled i hranidbene navike domaćih životinja u prosjeku poznaje $56,3 \%$ učenika, a nazive mužjaka, ženki i mladunčadi domaćih životinja u prosjeku razlikuje $66,4 \%$ učenika. Djevojčice i dječaci su pokazali isto znanje na pitanja o poznavanju izgleda i hranidbe domaćih životinja koje je u prosjeku iznosilo $56 \%$. U prosjeku djevojčice $\mathrm{s}$ rezultatom od $66,8 \%$ bolje poznaju nazive mužjaka, ženki i mladunčadi domaćih životinja od dječaka čiji prosječan rezultat iznosi $65,9 \%$. Učenici drugih razreda slabije poznaju domaće životinje u usporedbi s učenicima trećih i četvrtih razreda, dok učenici trećih razreda bolje poznaju fizičke značajke domaćih životinja od učenika drugih i četvrtih razreda. Mužjake, ženke i mladunčad bolje poznaju učenici četvrtih razreda u odnosu na učenike drugih i trećih razreda. Mišljenje učiteljica je da učenici malo poznaju domaće životinje, a kao razloge navode život u gradu te nedovoljan odlazak u prirodu i na selo gdje bi djeca mogla upoznati domaće životinje. Zaključeno je da učenici nižih razreda osnovnih škola Grada Zagreba malo poznaju izgled i hranidbene navike domaćih životinja, a vrlo dobro nazive 
Ivana Sever i sur.: Poznavanje domaćih životinja kod učenika nižih razreda osnovnih škola Grada Zagreba

mužjaka, ženki i mladunčadi domaćih životinja te da im vidovi izvanučioničke nastave na mjestima uzgoja uvelike pomažu bolje upoznati domaće životinje.

Ključne riječi: domaće životinje, učenici, učiteljice, Grad Zagreb

\section{ABSTRACT}

The previous research proved the positive effect of animals on the human life quality. It has been established that animals positively affect the mental and physical health, encourage people to social and physical activity and could be used for therapeutic purposes. The objectives of this study were to determine: (i) the knowledge of lower grade school children of domestic animals, (ii) the differences between girls and boys in the knowledge of domestic animals, (III) the differences among the second, third and fourth grade children in the knowledge of domestic animals, (IV) the teachers' opinion on the children's knowledge of domestic animals. The research was conducted at the Grassland Research Centre at the Faculty of Agriculture, University of Zagreb interviewing 528 lower grade children (from 2 nd to 4 th grade) ( 259 boys and 269 girls) and 28 teachers from seven elementary schools belonging the city of Zagreb during the school year 2016./2017. The results show that $56.3 \%$ of children on average are familiar with the domestic animals, look and their feeding habits while, on average $66.4 \%$ of the children differ the names of males, females and cubs. The girls and boys showed the same knowledge of the appearance and nutrition of domestic animals, which averaged 56\%. On average, $66.8 \%$ girls are better acquainted with male, female and young domestic animals than boys with an average score of $65.9 \%$. The second grade children are less familiar with domestic animals compared with the third and the fourth grade children. The third grade children are more familiar with the physical features of domestic animals comparing with the second and the fourth grade children. The fourth grade children achieved higher success in making differences among the animal categories (males, females and cubs) compared with the second and the third grade children. According to teachers' opinion the lower grade children are not good enough in the knowledge about domestic animals due to city life and rare country visits. It was concluded that the lower grade children in the city of Zagreb had poor knowledge about the external and the feeding habits of domestic animals while a very good knowledge in differing the names of males, females and cubs. Any form of outdoor education in animal raising areas can greatly increase the knowledge about domestic animals.

Keywords: domestic animals, school children, teachers, the city of Zagreb 
Ivana Sever i sur.: Poznavanje domaćih životinja kod učenika nižih razreda osnovnih škola Grada Zagreba

\section{UVOD}

U brojnim je istraživanjima utvrđen pozitivan utjecaj životinja na kvalitetu života ljudi. Utvrđeno je da životinje potiču ljude na društvene i fizičke aktivnosti (Hodgson i sur., 2015.). Životinje kod djece potiču razvoj odgovornosti (urednost, točnost i samodisciplinu) (Poresky i Hendrix, 1990.) i njihovog karaktera (Endenburg, 1991.) te pomažu djeci razvijati samopouzdanje. Kod djece se razvija veća suosjećajnost (Hodgson i sur., 2015.), emocionalno su razvijenija, osobito u segmentu samopoštovanja i samostalnosti (Wilks, 1999.). Životinje razvijaju kod djece maštu i sposobnost doživljavanja, posreduju u kontaktu djeteta s prirodom, odgovaraju na prva dječja pitanja o seksualnosti, o rođenju i o smrti, razvijaju osjećaj humanosti i socijalne empatije (Olbrich, 2001.).

Životinje imaju veliko značenje kao prijatelji (Casciotti i Zuckerman, 2016.), smanjuju osjećaj izolacije i usamljenosti (McNicholas i Collis, 2000.), smanjuju osjećaj apatije, depresivnosti i intenzitet suicidnih misli. Osim toga, daju čovjeku osjećaj da je potreban, a kod starijih osoba potiču kognitivno djelovanje i pobuđivanje sjećanja, samostalnost i neovisnost od pomoći drugih ljudi (Mallon, 2004.).

Životinje, kao kućni ljubimci, mogu pozitivno utjecati na zdravlje kardiovaskularnog sustava (Casciotti i Zuckerman, 2016.), umanjiti stres (Serpell, 2011.), sniziti krvni tlak, smanjiti napetost mišića lica, što dovodi do osmijeha i oslobađa osjećaj sreće i sigurnosti (Katcher i Beck, 1983.). Na psihičkom području djelovanja životinja na ljude, znanstvenici su razvili pojam „Pepeljugin efekt“", kojim se objašnjava njihovo bezuvjetno prihvaćanje ljudi, neovisno o socijalnim problemima i poremećajima. Njihova je privrženost trajna i nije kritična (Mallon, 2004.).

Poznato je korištenje životinja u terapeutske svrhe. Terapija životinjama (TŽ), kao npr. šetnja psa, četkanje mačke, igra s psom itd., koristi se u fizikalnoj terapiji. Osmišljeno je tako da se kod pacijenata koriste mišići, snaga i poboljšavaju motoričke sposobnosti (Chandler, 2005.). U širok spektar kliničkih problema uključena je TŽ, od simptoma autizma (Redefer i Goodman, 1989.), narušenog psihičkog zdravlja (Kanamori i sur., 2001.), emocionalnih poteškoća (Barker i Dowson, 1998.), problematičnog ponašanja (Nagengast i sur., 1997.) i fizičkih promjena (Nathanson i sur., 1997.). Korištenje životinja u svrhu terapije je korisno jer se životinja prirodno povezuje s ljudima (Olbrich i Otterstand, 2003.). Prilikom dovođena životinja u jednu od bolnica, bolesnici su postajali 
Ivana Sever i sur.: Poznavanje domaćih životinja kod učenika nižih razreda osnovnih škola Grada Zagreba

življi, veseliji i govorljiviji jer životinja razbija monotoniju, potiče želju bolesnika za kontaktom i stvara veselije ozračje (Zuckerman Itković i sur., 2007.).

Levison (1962.) navodi da korištenje domaćih životinja kao terapeuta dovodi do brže socijalizacije i emocionalne prilagodbe. Mallon (1994.) je utvrdio da su se ispitanici nakon posjete domaćim životinjama osjećali bolje, sretno i uzbuđeno jer su im životinje pomogle odagnati ljutnju i tugu, a farma je imala smirujući utjecaj.

Iako se u gradu Zagrebu smanjuje uzgoj domaćih životinja na malim seoskim gospodarstvima, na velikim se povećava (Program održivog razvoja poljoprivrede, šumarstva i ruralnog prostora Grada Zagreba 2016. - 2020.), u Republici Hrvatskoj se općenito nastavlja trend opadanja uzgoja domaćih životinja na seoskim domaćinstvima (Statistički ljetopis RH, 2015.), te bavljenje poljoprivrednom djelatnošću (Grgić i sur., 2010.). S obzirom na navedeno, osim gradske i seoska djeca su često uskraćena imati direktan kontakt $\mathrm{s}$ domaćim životinjama. Tome u prilog govori pilot istraživanje (Frljužec, 2014.) koje je pokazalo da seoska i gradska djeca predškolske dobi podjednako poznaju domaće životinje. U istraživanju poznavanja divljači, Jurčević Agić i sur. (2015.) navode da učenici nižih razreda ne poznaju dovoljno divljač svojega zavičaja. U istraživanju o poznavanju zaštićenih životinja Hrvatske učenika mlađe školske dobi, Marguš (2010.) navodi da su učenici prvog i četvrtog razreda pokazali najbolje znanje, a učenici drugog i trećeg razreda podjednako znanje. U dostupnoj znanstvenoj literaturi nije pronađeno istraživanje o poznavanju domaćih životinja učenika nižih razreda osnovnih škola grada Zagreba. Pretpostavka ovog istraživanja je bila da učenici nižih razreda osnovnih škola grada Zagreba malo poznaju domaće životinje.

Ciljevi ovog istraživanja bili su utvrditi: (I) koliko učenici nižih razreda osnovnih škola grada Zagreba poznaju domaće životinje, (II) postoje li razlike u poznavanju domaćih životinja djevojčica u odnosu na dječake, (III) postoje li razlike u poznavanju domaćih životinja između učenika drugog, trećeg i četvrtog razreda osnovnih škola, (IV) mišljenje učiteljica o poznavanju domaćih životinja učenika nižih razreda osnovnih škola. 
Ivana Sever i sur.: Poznavanje domaćih životinja kod učenika nižih razreda osnovnih škola Grada Zagreba

\section{MATERIJALI I METODE RADA}

Istraživanje o poznavanju domaćih životinja provedeno je u sklopu terenske nastave „Upoznajmo domaće životinje“, na pokušalištu Agronomskog fakulteta, Sveučilišta u Zagrebu, Centar za travnjaštvo na Medvednici. Stočni fond pokušališta sastoji se od: 60-tak goveda Charolais i Simentalske pasmine raznih kategorija (krave, junice, telad, bikovi), ovaca raznih kategorija (ovce, ovnovi, janjad, šilježice), magaraca, kobila, praščića, kokoši, patki, kunića, riba. Edukativna radionica Centra za travnjaštvo osmišljena je tako da učenici tijekom 4 sata prođu kroz tri etape učenja. Prva etapa podrazumijeva učenje o domaćim životinjama, njihovom izgledu, ponašanju, tjelesnim značajkama, hranidbenim navikama i načinu života na farmi. U drugoj etapi učenicima se $u$ laboratoriju približava znanost u vidu kemijskih pokusa i analiza hrane za hranidbu domaćih životinja. Treća etapa obuhvaća obilazak farme, druženje sa životinjama, hranidbu životinja, učenje postupanja sa životinjama, promatranje okruženja kakvo je ono zaista, te povezivanje stvarnog iskustva s nastavom u učionici i laboratoriju.

Istraživanje je provedeno anketiranjem učenika i učiteljica iz 7 osnovnih škola prilikom posjete pokušalištu tijekom školske godine 2016./2017. Za statističku analizu podataka korišteni su pokazatelji deskriptivne statistike. Od instrumenata istraživanja korištene su dvije ankete, jedna za učenike, a druga za učiteljice. Istraživanjem je obuhvaćeno ukupno 528 učenika nižih razreda (od 2. do 4. razreda), od čega 259 dječaka i 269 djevojčica. U istraživanje je bilo uključeno 28 učiteljica od kojih je 16 imalo do 15 godina radnog staža, 4 od 16 do 25 godina radnog staža i 8 učiteljica 26 i više godina radnog staža.

Dobiveni rezultati poznavanja domaćih životinja razvrstani su u 5 skupina: $0-20 \%$ točnih odgovora - uopće ne poznaju domaće životinje, $21-40 \%$ točnih odgovora - skoro pa ne poznaju domaće životinje, 41 - 60\% točnih odgovora malo poznaju domaće životinje, $61-80 \%$ točnih odgovora - vrlo dobro poznaju domaće životinje i 81 - 100\% točnih odgovora - odlično poznaju domaće životinje.

U anketi je učenicima postavljeno pitanje koliko su puta do sada uživo vidjeli kravu, ovcu, kozu, kunića, magarca i konja. Odgovori su razvrstani u 4 skupine: $0 \mathrm{x}$ - učenici nisu nikada vidjeli određenu domaću životinju, $1-2 \mathrm{x}-$ učenici su 1 - 2 puta uživo vidjeli određenu domaću životinju, $3-5 \mathrm{x}$ - učenici su 3 - 5 puta uživo vidjeli određenu domaću životinju, $>5 \mathrm{x}$ - učenici su više od 5 puta uživo vidjeli određenu domaću životinju. 
Ivana Sever i sur.: Poznavanje domaćih životinja kod učenika nižih razreda osnovnih škola Grada Zagreba

U anketi je učiteljicama bilo postavljeno pitanje u kojem su bili ponuđeni odgovori od 1 do 5 , gdje 1 znači da uopće ne poznaju domaće životinje, 2 - skoro pa ne poznaju domaće životinje, 3 - malo poznaju domaće životinje, 4 - vrlo dobro poznaju domaće životinje i 5 - odlično poznaju domaće životinje.

\section{REZULTATI I RASPRAVA REZULTATA ISTRAŽIVANJA}

Ankete učenika

U tablici 1. je prikazano koliko su puta učenici nižih razreda osnovnih škola Grada Zagreba uživo vidjeli pojedine vrste domaćih životinja.

Tablica 1. Prikaz koliko su puta učenici nižih razreda osnovnih škola Grada Zagreba uživo vidjeli pojedine domaće životinje (\%)

Table 1 How many times have children in lower grades of primary schools in Zagreb seen certain domestic animals alive (\%)

\begin{tabular}{|c|c|c|c|c|}
\hline \multirow{2}{*}{$\begin{array}{c}\text { KOLIKO STE PUTA } \\
\text { UŽIVO VIDJELI: } \\
\begin{array}{c}\text { How many times } \\
\text { have you seen alive: }\end{array}\end{array}$} & \multicolumn{4}{|c|}{$\begin{array}{c}\text { \% točnih odgovora } \\
\% \text { of correct answers }\end{array}$} \\
\cline { 2 - 5 } & $0 \mathrm{x}$ & $1-2 \mathrm{x}$ & $3-5 \mathrm{x}$ & $>5 \mathrm{x}$ \\
\hline Kravu/Cow & 12,9 & 35 & 23,5 & 28,6 \\
\hline Ovcu/Sheep & 13,6 & 37,9 & 22,9 & 25,6 \\
\hline Kozu/Goat & 17,4 & 40,3 & 21,2 & 21 \\
\hline Kunića/Rabbit & 26,9 & 33 & 16,5 & 23,7 \\
\hline Magarca/Donkey & 19,9 & 46,4 & 15,7 & 18 \\
\hline Konja/Horse & 4,2 & 20,1 & 28,8 & 47 \\
\hline
\end{tabular}

Iz rezultata prikazanih u tablici 1. vidljivo je da je konj jedina životinja koju je najviše učenika vidjelo više od 5 x (47\%) te da je najmanje učenika koji nikada nisu vidjeli konja $(4,2 \%)$. Jedan od razloga navedenog može biti činjenica da su anketirani učenici iz škola Grada Zagreba, a vodeće županije po uzgoju konja u Republici Hrvatskoj su Sisačko - moslavačka i Zagrebačka županija s Gradom Zagrebom (kao središtem uzgoja sportskih konja) (Baban i sur., 2012.). Više je učenika vidjelo kravu, ovcu, kozu, kunića i magarca $1-2 \mathrm{x}$, nego $3-5 \mathrm{x}$, izuzev konja kojeg je više učenika vidjelo uživo $3-5 \mathrm{x}$, nego $1-2 \times$ (tablica 1$)$. 
Ivana Sever i sur.: Poznavanje domaćih životinja kod učenika nižih razreda osnovnih škola Grada Zagreba

U tablici 2. prikazana je usporedba odgovora dječaka i djevojčica nižih razreda osnovnih škola Grada Zagreba koliko su puta uživo vidjeli pojedine domaće životinje.

Tablica 2. Odgovori dječaka i djevojčica nižih razreda osnovnih škola Grada Zagreba koliko su puta uživo vidjeli pojedine vrste domaćih životinja (\%)

Table 2 Responses of boys and girls in lower grades of primary schools in Zagreb to how many times they have seen certain types of domestic animals alive (\%)

\begin{tabular}{|c|c|c|c|c|c|c|c|c|}
\hline $\begin{array}{c}\text { KOLIKO STE } \\
\text { PUTA UŽIVO } \\
\text { VIDJELI: } \\
\begin{array}{c}\text { How many times } \\
\text { have you seen } \\
\text { alive: }\end{array}\end{array}$ & \multicolumn{2}{|c|}{$\begin{array}{c}\% \text { točnih odgovora } \\
\% \text { of correct answers }\end{array}$} \\
\cline { 2 - 10 } & $\begin{array}{c}\text { Dječaci } \\
\text { Boys }\end{array}$ & $\begin{array}{c}\text { Djevojčice } \\
\text { Girls }\end{array}$ & $\begin{array}{c}\text { Dječaci } \\
\text { Boys }\end{array}$ & $\begin{array}{c}\text { Djevojčice } \\
\text { Girls }\end{array}$ & $\begin{array}{c}\text { Dječaci } \\
\text { Boys }\end{array}$ & $\begin{array}{c}\text { Djevojčice } \\
\text { Girls }\end{array}$ & $\begin{array}{c}\text { Dječaci } \\
\text { Boys }\end{array}$ & $\begin{array}{c}\text { Djevojčice } \\
\text { Girls }\end{array}$ \\
\hline Kravu/Cow & 11,6 & 14,1 & 37,9 & 32,3 & 19,3 & 27,5 & 30,9 & 26,4 \\
\hline Ovcu/Sheep & 13,1 & 14,1 & 35,9 & 39,8 & 23,6 & 22,3 & 27,4 & 23,8 \\
\hline Kozu/Goat & 18,1 & 16,7 & 41,3 & 39,4 & 17,8 & 24,5 & 22,8 & 19,3 \\
\hline Kunića/Rabbit & 33,2 & 20,8 & 31,3 & 34,6 & 15,4 & 37,2 & 20 & 27,1 \\
\hline Magaraca/Donkey & 23,9 & 16 & 44 & 48,7 & 14,6 & 16,7 & 17 & 19 \\
\hline Konja/Horse & 5,4 & 3 & 22,8 & 37,2 & 29 & 28,6 & 42,5 & 51,3 \\
\hline
\end{tabular}

Uzme li se u obzir razlika djevojčica i dječaka (tablica 2.) jesu li vidjeli određenu domaću životinju ili nisu, neovisno o tome koliko puta, može se vidjeti da su dječaci u prosjeku kravu $(29,4 \%)$ i ovcu $(29 \%)$ vidjeli češće od djevojčica kod kojih je prosjek za kravu iznosio $28,7 \%$, a za ovcu $28,6 \%$. Djevojčice su kozu (27,7\%), kunića (33\%), magarca (28,1\%) i konja (39\%) vidjele češće od dječaka kod kojih je prosjek za kozu iznosio 27,3\%, kunića $22,2 \%$, magarca $25,2 \%$ i konja $31,4 \%$.

U anketi su bile postavljene tvrdnje „Često posjećujem uzgajivača domaćih životinja!“ i „Želio bih češće izlete na mjesta uzgoja domaćih životinja!“. Učenici su trebali zaokružiti „DA“ ili „NE“. Prema rezultatima istraživanja, $1,5 \%$ učenika nikada nije vidjelo niti jednu domaću životinju uživo, što je u suglasju s mišljenjem učiteljica koje navode i razloge nepoznavanja domaćih životinja učenika (slika 3). Isto se može potkrijepiti i odgovorima učenika prema kojima $44,7 \%$ učenika ima priliku češće posjetiti uzgajivača domaćih životinja na selu. Osim toga, $89,4 \%$ učenika je navelo da bi željelo češće ići na izlet u prirodu i vidjeti domaće životinje. 
Ivana Sever i sur.: Poznavanje domaćih životinja kod učenika nižih razreda osnovnih škola Grada Zagreba

U drugoj skupini pitanja cilj je bio saznati koliko učenici nižih razreda osnovnih škola Grada Zagreba poznaju izgled i hranidbu domaćih životinja. U anketi su postavljena pitanja „Koje su od ponuđenih životinja domaće?“, „Koje životinje imaju rogove?“, „Koje životinje imaju perje?“ i „Koje životinje jedu sijeno?", a da bi odgovor bio vrednovan kao točan, učenici su trebali zaokružiti 3 do 4 domaće životinje, ovisno o pitanju.

Broj točnih odgovora te razlika u točnim odgovorima između djevojčica i dječaka prikazana je u tablici 3.

Tablica 3. Točni odgovori djevojčica i dječaka nižih razreda osnovnih škola Grada Zagreba na pitanja o poznavanju izgleda i hranidbe domaćih životinja (\%)

Table 3 Correct answers of boys and girls in lower grades of primary schools in Zagreb to questions on their knowledge of looks and animal nutrition (\%)

\begin{tabular}{|c|c|c|c|c|}
\hline \multirow{2}{*}{$\begin{array}{c}\text { Pitanje/zadatak } \\
\text { Question/task }\end{array}$} & $\begin{array}{c}\text { Zaokruži domaće } \\
\text { životinje! } \\
\text { Round the } \\
\text { domestic animals! }\end{array}$ & $\begin{array}{c}\text { Koje životinje } \\
\text { imaju rogove? } \\
\text { Which animals } \\
\text { have horns? }\end{array}$ & $\begin{array}{c}\text { Koje životinje } \\
\text { imaju perje? } \\
\text { Which animals } \\
\text { have feathers? }\end{array}$ & $\begin{array}{c}\text { Koje životinje } \\
\text { jedu sijeno? } \\
\text { Which animals } \\
\text { eat hay? }\end{array}$ \\
\hline Dječaci/Boys & 64,1 & \multicolumn{4}{|c|}{$\begin{array}{c}\text { \% točnih odgovora } \\
\text { o ofrect answers }\end{array}$} \\
\hline Djevojčice/Girls & 67,3 & 40,5 & 76,4 & 43,2 \\
\hline Ukupno/Total & 65,7 & 34,6 & 84,4 & 39,8 \\
\hline
\end{tabular}

Nadalje, cilj istraživanja je bio utvrditi koliko učenici nižih razreda osnovnih škola Grada Zagreba poznaju nazive mužjaka, ženki i mladunčadi domaćih životinja. Navedeno je 8 tvrdnji na koje su učenici trebali odgovoriti „T“ ukoliko je tvrdnja točna ili „N" ukoliko je netočna.

Tablica 4. prikazuje postotak točnih odgovora djevojčica i dječaka nižih razreda osnovnih škola Grada Zagreba na tvrdnje o poznavanju naziva mužjaka, ženki i mladunčadi domaćih životinja. 
Ivana Sever i sur.: Poznavanje domaćih životinja kod učenika nižih razreda osnovnih škola Grada Zagreba

Tablica 4. Prikaz točnih odgovora djevojčica i dječaka nižih razreda osnovnih škola Grada Zagreba na tvrdnje o poznavanju naziva mužjaka, ženki i mladunčadi domaćih životinja

Table 4 Correct answers of girls and boys of the lower grades of elementary schools of the City of Zagreb to the claims of knowing the names of male, female and young domestic animals

\begin{tabular}{|c|c|c|c|}
\hline \multirow{2}{*}{$\begin{array}{l}\text { Tvrdnja } \\
\text { Averment }\end{array}$} & $\begin{array}{l}\text { Dječaci } \\
\text { Boys }\end{array}$ & $\begin{array}{l}\text { Djevojčice } \\
\text { Girls }\end{array}$ & $\begin{array}{l}\text { Ukupno } \\
\text { Total }\end{array}$ \\
\hline & \multicolumn{3}{|c|}{$\begin{array}{l}\% \text { točnih odgovora } \\
\% \text { of correct answers }\end{array}$} \\
\hline $\begin{array}{l}\text { Mužjak krave je bik. } \\
\text { Male cow is a bull. }\end{array}$ & 84,6 & 80,3 & 82,4 \\
\hline $\begin{array}{l}\text { Tele je mladunče krave i bika. } \\
\text { Calf is a cub of cow and bull. }\end{array}$ & 76,8 & 79,2 & 78 \\
\hline $\begin{array}{l}\text { Mužjak ovce je jarac. } \\
\text { Male sheep is a capricorn. }\end{array}$ & 39,4 & 40,1 & 39,8 \\
\hline $\begin{array}{l}\text { Kobila je ženka konja. } \\
\text { Female horse is a mare. }\end{array}$ & 65,6 & 66,2 & 65,9 \\
\hline $\begin{array}{l}\text { Janje je mladunče koze. } \\
\text { Lamb is a cub of goat. }\end{array}$ & 40,2 & 40,5 & 40,3 \\
\hline $\begin{array}{l}\text { Pijetao je mužjak kokoši. } \\
\text { Male fowl is a rooster. }\end{array}$ & 87,6 & 81,8 & 84,7 \\
\hline $\begin{array}{l}\text { Pile je mladunče patke. } \\
\text { Chicken is a cub of duck. }\end{array}$ & 69,5 & 74,7 & 72,2 \\
\hline $\begin{array}{l}\text { Ždrijebe je mladunče kobile. } \\
\text { Foal is a cub od mare. }\end{array}$ & 63,7 & 71,7 & 67,8 \\
\hline $\begin{array}{l}\text { Sve točno odgovoreno } \\
\text { All correct answered }\end{array}$ & 10,4 & 15,2 & 12,9 \\
\hline
\end{tabular}

Rezultate anketa učiteljica potvrđuju i učenici svojim odgovorima u drugoj i trećoj skupini pitanja. Na pitanja o poznavanju izgleda i hranidbenim navikama životinja učenici su pokazali da u prosjeku malo poznaju domaće životinje (tablica 3.). U prosjeku su imali 56,3\% točnih odgovora (tablica 3.), što se poklapa s odgovorima da $44,7 \%$ učenika na selu posjećuje uzgajivača domaćih životinja. Djevojčice i dječaci su pokazali isto znanje na pitanja o poznavanju izgleda i hranidbe domaćih životinja koje je u prosjeku iznosilo 56\%. 
Ivana Sever i sur.: Poznavanje domaćih životinja kod učenika nižih razreda osnovnih škola Grada Zagreba

Vrlo dobro znanje, s prosjekom od $66,4 \%$ učenici su pokazali u odgovorima na pitanja o poznavanju mužjaka, ženki i mladunčadi domaćih životinja (tablica 4.). Za razliku od navedenog, $u$ istraživanju poznavanja divljači svojega zavičaja, Jurčević Agić i sur. (2015.) su utvrdili da samo 43\% učenika nižih razreda osnovne škole dobro poznaje divljač svojega zavičaja te da nazive mužjaka, ženki i mladunčadi poznaju loše i slabo ih razlikuju. U prilog navedenom govori činjenica da su učenicima bliže domaće od divljih životinja, što potvrđuju i ranija istraživanja (Jurčević Agić i sur., 2015.). U prosjeku djevojčice s rezultatom od $66,8 \%$ bolje poznaju nazive mužjaka, ženki i mladunčadi domaćih životinja od dječaka čiji prosječan rezultat iznosi $65,9 \%$. Potrebno je istaknuti da su i djevojčice $(15,2 \%)$ i dječaci $(10,4 \%)$ imali nizak postotak točnih odgovora na svih osam pitanja ukupno (tablica 4.).

U tablicama 5. i 6. uspoređeni su rezultati anketa učenika drugog, trećeg i četvrtog razreda osnovnih škola Grada Zagreba o poznavanju izgleda, hranidbenih navika te naziva mužjaka, ženki i mladunčadi domaćih životinja.

Tablica 5. Usporedba poznavanja domaćih životinja između učenika drugog, trećeg i četvrtog razreda osnovnih škola Grada Zagreba (\%)

Table 5 Comparison of the knowledge of domestic animals among second, third and fourth grade schoolchildren of the City of Zagreb (\%)

\begin{tabular}{|c|c|c|c|c|}
\hline $\begin{array}{c}\text { Pitanje/zadatak } \\
\text { Question/task }\end{array}$ & $\begin{array}{l}\text { ZAOKRUŽI } \\
\text { DOMAĆE } \\
\text { ŽIVOTINJE! } \\
\text { Round the } \\
\text { domestic } \\
\text { animals! }\end{array}$ & $\begin{array}{c}\text { KOJE } \\
\text { ŽIVOTINJE } \\
\text { IMAJU } \\
\text { ROGOVE? } \\
\text { Which animals } \\
\text { have horns? }\end{array}$ & $\begin{array}{l}\text { KOJE } \\
\text { ŽIVOTINJE } \\
\text { IMAJU PERJE? } \\
\text { Which animals } \\
\text { have feathers? }\end{array}$ & $\begin{array}{c}\text { KOJE } \\
\text { ŽIVOTINJE } \\
\text { JEDU SIJENO? } \\
\text { Which animals } \\
\text { eat hay? }\end{array}$ \\
\hline $\begin{array}{l}\text { Razred } \\
\text { Grade }\end{array}$ & \multicolumn{4}{|c|}{$\begin{array}{l}\% \text { točnih odgovora } \\
\% \text { of correct answers }\end{array}$} \\
\hline 2. & 61,9 & 40,3 & 76,1 & 41,3 \\
\hline 3. & 72,3 & 35,3 & 84,9 & 42,9 \\
\hline 4. & 70,7 & 32,3 & 86,9 & 41,4 \\
\hline
\end{tabular}

Iz tablice 5. vidljivo je da učenici trećih razreda bolje poznaju fizičke značajke i hranidbene navike domaćih životinja od učenika drugih i četvrtih razreda. 
Ivana Sever i sur.: Poznavanje domaćih životinja kod učenika nižih razreda osnovnih škola Grada Zagreba

Tablica 6. Usporedba poznavanja naziva mutžjaka, ženki i mladunčadi domaćih životinja između učenika drugog, trećeg i četvrtog razreda osnovnih škola Grada Zagreba (\%)

Table 6 Comparison of the knowledge of male, female and young domestic animals among second, third and fourth grade schoolchidren of the City of Zagreb (\%)

\begin{tabular}{|c|c|c|c|}
\hline \multirow{3}{*}{$\begin{array}{c}\text { Tvrdnja } \\
\text { Averment }\end{array}$} & \multicolumn{3}{|c|}{$\begin{array}{l}\text { Razred } \\
\text { Grade }\end{array}$} \\
\hline & 2. & 3. & 4. \\
\hline & \multicolumn{3}{|c|}{$\begin{array}{l}\% \text { točnih odgovora } \\
\% \text { of correct answers }\end{array}$} \\
\hline $\begin{array}{l}\text { Mužjak krave je bik. } \\
\text { Male cow is a bull. }\end{array}$ & 76,8 & 91,6 & 89,9 \\
\hline $\begin{array}{l}\text { Tele je mladunče krave i bika. } \\
\text { Calf is a cob of cow and bull. }\end{array}$ & 75,8 & 82,4 & 80,8 \\
\hline $\begin{array}{l}\text { Mužjak ovce je jarac. } \\
\text { Male sheep is a capricorn. }\end{array}$ & 39 & 43,7 & 33,3 \\
\hline $\begin{array}{l}\text { Kobila je ženka konja. } \\
\text { Female horse is a mare. }\end{array}$ & 63,9 & 62,2 & 77,8 \\
\hline $\begin{array}{l}\text { Janje je mladunče koze. } \\
\text { Lamb is a cub od goat. }\end{array}$ & 39 & 32,8 & 52,5 \\
\hline $\begin{array}{l}\text { Pijetao je mužjak kokoši. } \\
\text { Male fowl is a rooster. }\end{array}$ & 79,4 & 92,4 & 92,9 \\
\hline $\begin{array}{l}\text { Pile je mladunče patke. } \\
\text { Chicken is a cub of duck. }\end{array}$ & 69 & 72,3 & 80,8 \\
\hline $\begin{array}{l}\text { Ždrijebe je mladunče kobile. } \\
\text { Foal is a cub of mare. }\end{array}$ & 64,2 & 60,5 & 85,9 \\
\hline $\begin{array}{l}\text { Sve točno odgovoreno } \\
\text { All correct answered }\end{array}$ & 12,3 & 12,6 & 15,2 \\
\hline
\end{tabular}

Nazive mužjaka, ženki i mladunčadi bolje razlikuju učenici četvrtih razreda (tablica 6.) u odnosu na učenike drugih i trećih razreda. Učenici drugih razreda u prosjeku slabije poznaju domaće životinje u usporedbi s učenicima trećih i četvrtih razreda. Navedeno se može obrazložiti i osnovnoškolskim planom i programom po kojem učenici u trećem razredu uče o selu, izgledu zavičaja, gospodarskim djelatnostima i obilježjima zavičajne regije, a u četvrtom razredu taj program nadopunjuju temama o životu životinja, životu biljaka i slično (Nastavni plan i program za osnovnu školu, 2013.). Potrebno je istaknuti da učenici sva tri razreda imaju nizak postotak točnih odgovora na svih osam tvrdnji (tablica 6.). 
Ivana Sever i sur.: Poznavanje domaćih životinja kod učenika nižih razreda osnovnih škola Grada Zagreba

Ankete učiteljica

Na slici 1. Prikazano je mišljenje učiteljica, s obzirom na njihovo radno iskustvo, o poznavanju domaćih životinja kod učenika nižih razreda osnovnih škola Grada Zagreba.

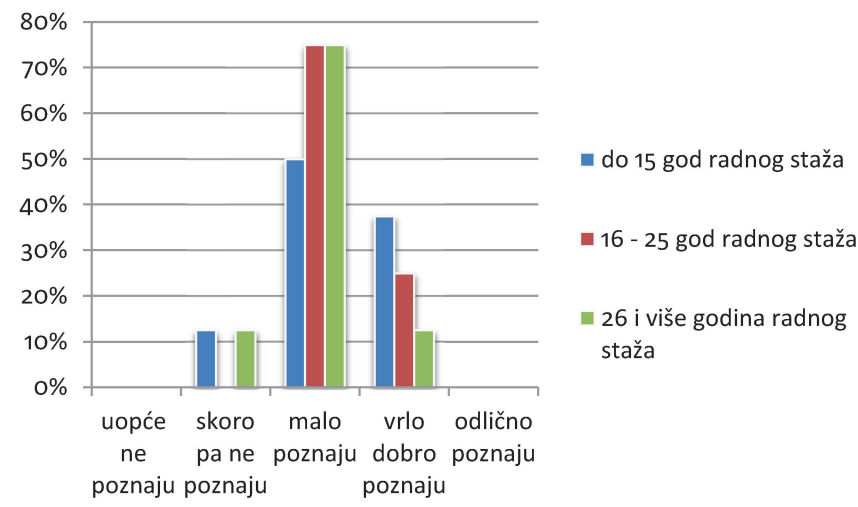

Slika 1. Mišljenje učiteljica, s obzirom na njihovo radno iskustvo, o poznavanju domaćih životinja kod učenika nižih razreda osnovnih škola Grada Zagreba (\%)

Figure 1 Teacher's opinion, given their work experience, on the knowledge of domestic animals in lower grades of elementary schools of the City of Zagreb (\%)

Na slici 2. prikazano je mišljenje učiteljica, bez obzira na radno iskustvo, o poznavanju domaćih životinja kod učenika nižih razreda osnovnih škola Grada Zagreba.

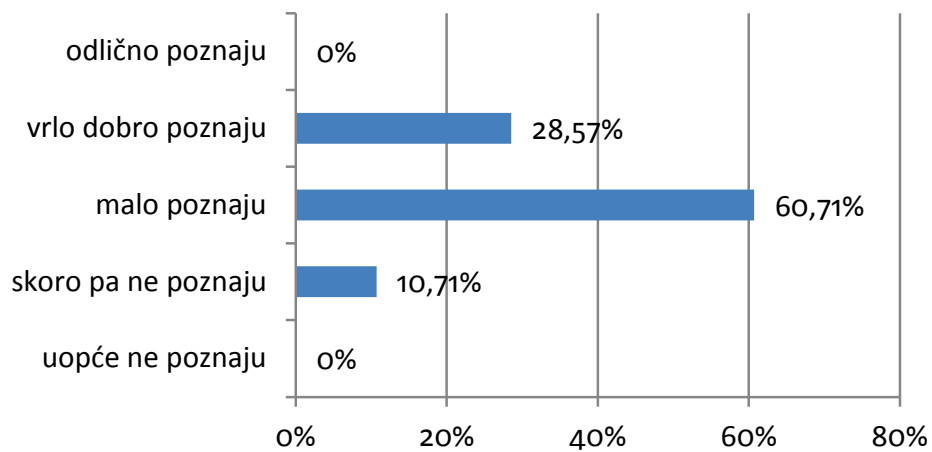

Slika 2. Mišljenje učiteljica, bez obzira na radno iskustvo, o poznavanju domaćih životinja kod učenika nižih razreda osnovnih škola Grada Zagreba (\%)

Figure 2 Teacher's opinion, regardless of work experience, on the knowledge of domestic animals of lower grade schoolchildren of the City of Zagreb (\%) 
Ivana Sever i sur.: Poznavanje domaćih životinja kod učenika nižih razreda osnovnih škola Grada Zagreba

Drugo pitanje postavljeno učiteljicama bilo je „Ako smatrate da učenici ne poznaju dovoljno dobro domaće životinje, koji je razlog tome?" Učiteljice na ovo pitanje nisu imale u anketi ponuđeni odgovor.

$\mathrm{Na}$ slici 3. prikazano je mišljenje učiteljica o razlozima nedovoljnog poznavanja domaćih životinjama kod učenika nižih razreda osnovnih škola Grada Zagreba.

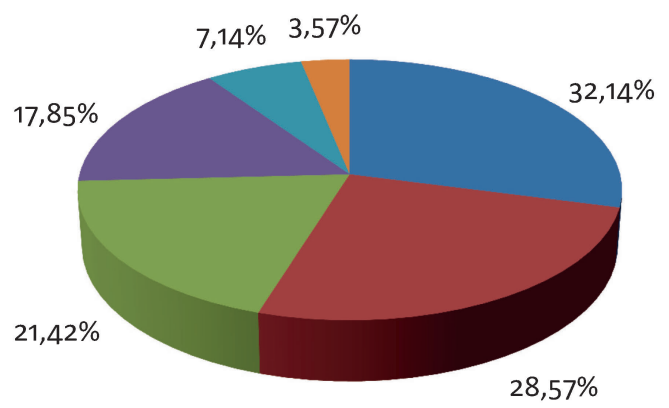

$$
\begin{aligned}
& \text { nema odgovora } \\
& \text { život u gradu } \\
& \text { roditelji djecu ne vode u } \\
& \text { prirodu i na selo } \\
& \text { učenici se nisu susreli s } \\
& \text { životinjama } \\
& \text { škola ne organizira } \\
& \text { dovoljno izleta u prirodu } \\
& \text { nezainteresiranost za } \\
& \text { životinje }
\end{aligned}
$$

Slika 3. Mišljenje učiteljica o razlozima nedovoljnog poznavanja domaćih životinjama kod učenika nižih razreda osnovnih škola Grada Zagreba (\%)

Figure 3 Teacher's opinion on reasons for insufficient knowledge of domestic animals by children of lower grades of elementary schools of the City of Zagreb (\%)

Rezultati istraživanja, prema odgovorima učiteljica, pokazuju da je poznavanje domaćih životinja kod učenika nižih razreda osnovnih škola Grada Zagreba razreda osrednje, odnosno da malo poznaju domaće životinje. Razlozi koje navodi većina učiteljica su život u gradu te nedovoljan broj odlazaka u prirodu i na selo gdje se domaće životinje mogu upoznati.

\section{ZAKLJUČAK}

Učenici nižih razreda osnovnih škola Grada Zagreba malo poznaju izgled i hranidbene navike domaćih životinja, a vrlo dobro nazive mužjaka, ženki i mladunčadi domaćih životinja te im izvanučionička nastava na mjestima uzgoja pomaže usvojiti znanja o domaćim životinjama. Osim što je neophodno provoditi izvanučioničku nastavu za stjecanje novih znanja i iskustava učenika, kao što je upoznavanje domaćih životinja, te navod da prirodno i društveno 
Ivana Sever i sur.: Poznavanje domaćih životinja kod učenika nižih razreda osnovnih škola Grada Zagreba

okruženje predstavlja prirodne izvore znanja koji su adekvatni za provedbu raznovrsnih pedagoških aktivnosti (Bognar i Matijević, 2002.), potrebno je i nadalje održavati, ali i intenzivirati izvanučioničku nastavu učenika kao sastavni dio nastavnog rada u školama.

Naredno istraživanje bit će usmjereno na utvrđivanje prednosti i ograničenja izvanučioničke nastave u prirodi za učenike osnovnih škola Grada Zagreba.

\section{LITERATURA}

1. Aračić, N. (2008.): Praktični rad u nastavi prirode i društva. Diplomski rad. Sveučilište J.J. Strossmayera, Učiteljski fakultet u Osijeku, Dislocirani studij u Slavonskom Brodu, Osijek

2. Baban, M., Gregić, M., Korabi, N., Antunović, B. (2012.): Konjogojstvo u Republici Hrvatskoj - stanje i perspektiva. Krmiva 54 . Zagreb 3; 89-98

3. Barker, S.B., Dawson, K.S. (1998.): The effects of animal-assisted therapy on anxiety ratings of hospitalized psychiatric patients. Psychiatric Services 49, 797801.

4. Bognar, L. Matijević, M. (2002.): Didaktika. Školska knjiga, Zagreb.

5. Casciotti, D., Zuckerman, D. (2016.): The benefits of pets for human health. National Center for Health Research. http://center4research.org/healthy-livingprevention/pets-and-health-the-impact-of-companion-animals/ Pristup 10.11.2016

6. Chandler, C.K. (2005.): Animal Assisted Therapy in Counselling. Routledge, New York.https://tandfbis.s3.amazonaws.com/rtmedia/pp/common/samplechapters/978 0415888332.pdf Pristup 03.05.2017

7. Endenburg, N. (1991.): Animals as Companions; Demographic, Motivational and Ethical Aspects of Companion Animal Ownership. Thesis, University of Amsterdam.

8. Frljužec, D. (2014.): Poznavanje životinja iz neposrednog okoliša djece predškolske dobi u selu i gradu. Diplomski rad. Sveučilište Josipa Jurja Strossmayera u Osijeku, Fakultet za odgojne i obrazovne znanosti, Osijek.

9. Grgić, I., Georgijevski, D., Kovačić, D., Franić, R., Tratnik, M. (2010.): Ocjena postojećeg stanja ruralnog prostora, istraživanje i utvrđivanje prioriteta i ciljeva razvitka ruralnog prostora na području Zagreba za razdoblje od 2009. do 2016. godine. Agronomski fakultet. Zagreb.

10. Hodgson, K., Barton, L., Darling, M., Antao, V., Kim, F. A. \& Monavvari, A. (2015.): Pets' Impact on Your Patients' Health: Leveraging Benefits and Mitigating Risk. The Journal of the American Board of Family Medicine, 28(4), 526-534. 
Ivana Sever i sur.: Poznavanje domaćih životinja kod učenika nižih razreda osnovnih škola Grada Zagreba

11. Jurčević Agić, I., Bogut, I., Užarević, Z., Radić, M., Popović, Ž. (2015.): Poznavanje divljači nizinskog zavičaja kod djece mlađe školske dobi. Zbornik sažetaka 4. Simpozija s međunarodnim sudjelovanjem Kopački rit jučer, danas, sutra. Tikveš - Kopačevo, 29-30.

12. Kanamori, M., Suzuki, M., Yamamoto, K., Kanda, M., Matsui,Y., Kojima, E., Fukawa, H., Sugita, T., Oshiro, H. (2001.): A day care program and evaluation of animal assisted therapy (AAT) for theelderly withsenile dementia. American Journal of Alzheimer's Disease and Other Dementias 16, 234-239.

13. Katcher, AH., Beck, AM. (1983.): Sicherheit und Vertrautheit: Mench - Tier Beziehung. Prvi međunarodni simpozij o terapiji uz pomoć Životinja. Beč, 113-5.

14. Levinson, B. (1962.): The dog as co-therapist Mental hygiene, 46,59-65.

15. Mallon, G.P. (1994.): Cow as Co-Therapist: Utilization of Farm Animals as Therapeutic Aides with Children in Residential Treatment. Child and Adolescent Social Work Journal. Volume 11, Number 6, December 1994.

16. Mallon, G.P. (2004.): Some of our best therapists are dogs. Child and Youth Care Forum. Gostujuće izlaganje Universitet Erlagen.

17. Marguš, N. (2010.): Poznavanje zaštićenih životinja Hrvatske učenika mlađe školske dobi. Diplomski rad. Sveučilište Josipa Jurja Strossmayera u Osijeku, Učiteljski fakultet, Osijek.

18. McNicholas, J., Collis, G.M. (2000.): Dogs as catalysts for social interactions: robustness of the effect. British Journal of Psychology 91, 61-70.

19. Nagengast, S.L., Baun, M.M., Megel, M., Leibowitz, J.M. (1997.): The effects of the presence of a companion animal on physiological arousal and behavioural distress in children during a physical examination. Journal of Pediatric Nursing 12, 323-330.

20. Nastavni plan i program za osnovnu školu, Ministarstvo znanosti, obrazovanja i športa. Zagreb, 2013.

21. Nathanson, D.E., Castro, D., Friend, H., McMahon, M. (1997.): Effectiveness of shortterm dolphin-assisted therapy for children with severe disabilities. Anthrozoös $10,90-100$.

22. Olbrich, E., Otterstedt, E. (2003.): Menschen brauchen Tiere: Grundlangen und Praxis der tiergestützten Pädagogik und Therapie. Frankh-Kosmos, Stuttgart.

23. Olbrich, E. (2001.): Vortrang beim Kurs Tiergestutzte Pedagogik/ Tiergestutzte Therapie. Munchen: Wedemark 2001;132(2):114.

24. Poresky, R. H., Hendrix, C. (1990.): Differential effects of pet presence and petbonding on young children. Psychological Reports 66: 931-936. 
Ivana Sever i sur.: Poznavanje domaćih životinja kod učenika nižih razreda osnovnih škola Grada Zagreba

25. Gradska skupština Grad Zagreba (2016.): Program održivog razvoja poljoprivrede, šumarstva i ruralnog prostora Grada Zagreba 2016. - 2020. Službeni glasnik Grada Zagreba 19/99, 19/01, 20/01 - pročišćeni tekst, 10/04, 18/05, 2/06, 18/06, 7/09, $16 / 09,25 / 09,10 / 10, / 13,24 / 13$ i $2 / 15$.

26. Redefer, L.A., Goodman, J.F., (1989.): Brief report: pet-facilitated therapy with autistic children. Journal of Autism and Developmental Disorders 19, 461-467.

27. Serpell, J.A. (2011.): Historical and cultural perspectives on human-pet interactions. In McCardel, P., McCune, S., Griffin, J.A., et al, Animals in Our Lives (pp. 7-22). Baltimore: Paul H. Brookes Publishing Co.

28. Statistički ljetopis Republike Hrvatske. 2015. http://www.dzs.hr/Hrv_Eng/ljetopis/2015/sljh2015.pdf. Pristup 26.4.2017.

29. Wilks, K. (1999.): Whendogsareman'sbestfriend- thehealthbenefitsofcompanion animals in the modern society. In: Urban Animal Management (UAM) Conference Proceedings Gold Coast.

30. Zuckerman Itković, Z., Petranović, D., Barešić, K. (2007.): Ergoterapija uz pomoć životinja. Medicina 2007; 43; 155-164.

Adresa autora - Author's address:

Ivana Sever, mag. ing. agr.

e-mail: isever@agr.hr,

Prof. dr. sc. Marina Vranić

e-mail:mvranic@agr.hr,

Prof. dr. sc. Krešimir Bošnjak

e-mail:kbosnjak@agr.hr

Ivana Čačić, dipl. ing.

e-mail: icacic@agr.hr,

Martina Protulipac, mag. ing. agr.

e-mail: mprotulipac@agr.hr,

Mirjana Klepac, mag. paed. relig. et. catech.

e-mail: mklepac@agr.hr,

Sveučilište u Zagrebu Agronomski fakultet

Zavod za specijalnu proizvodnju bilja Centar za travnjaštvo

Svetošimunska cesta 25, 10000 Zagreb
Primljeno - Received:

15.03.2017. 